\title{
Measures Provided by the Albanian Legislation for Consumer Protection from Discrimination
}

\author{
MSc. Belinda Halilaj \\ “Ismail Qemali"University, Vlora, Albania \\ Email: belinda2012halilaj@gmail.com
}

Doi:10.5901/ajis.2016.v5n3s1p83

\begin{abstract}
Consumer protection in Albania is taking greater importance in this recent years. Despite measures for consumer protection, cases of consumer discrimination in the provision of goods and services on the market are present. In this paper we will discuss consumer protection from discrimination based on the analyzing of measures taken for the consumers protection and the efforts of our countrys' for establishment a higher level consumer protection. Approval and implementation of policies that are creating a general legal environment and institutional that guarantees consumers protection from discrimination have yielded positive effects. The reasons for which customers are discriminated were differing, the implementation of this measures has been necessary because no consumer can not discriminated. Direct discrimination of consumers based on gender and origin were the most widespread forms of discrimination. This kind of discrimination was a serious problem in the state of law, with the prevention of new cases in the market, we can say that we have a consumer protected. With the approval of law of 2008 we can say that we have a consumer protected because the previous laws had not yielded positive effects. With the approval of this law are create state mechanisms which have strengthened consumer protection and it have prevented cases of consumer discrimination.
\end{abstract}

Keywords: consumer, discrimination, market, price differentiation, measures implemented.

\section{Introduction}

Each of us is a consumer of goods and services. Society within which we live and are part asks how to meet basic needs of measures to protect and ensure the customer. An effective policy on the customer can change for the better the lives of citizens. The question arises what would you mean by customer? Consumer means any natural person who buys and uses goods or services to meet the needs of people and not for purposes that are related to commercial activity, namely for the resale of those goods. Develop and implement policies to create an environment of general legal and institutional framework that guarantees consumers protection of health, safety and economic interests, improvement of education, information and awareness, support for effective implementation of their rights in order empowering consumers and increase their confidence in making purchases of goods and services in the market, making the market work for them. In some cases found in the market is a price differentiation.

Price differentiation is a "pricing strategy" where the goods or services identical or similar are offered at different prices from the same provider in various markets or territories.

Discrimination in price from geographical aspect occurs when there is an accusation against a business that offers different prices for the same product in two or more different countries simultaneously.

Education and awareness of consumers and traders is without doubt one of the elements that contribute to providing a customer-friendly climate and increasing the transparency of commercial practices. For this purpose, aiming to recognize the legal framework of consumer protection and product safety is being developed an awareness campaign for consumers and economic operators, addressing customers, students, economic operators and media. The issue of consumer education in school is applicable in the main documents of the basic education curriculum and secondary. In basic education, the issue of consumer education is included in the program of social education course, in line civic education and economic education that permeates this case, along the lines of other knowledge and skills.

\section{Measures Provided for Consumer Protection}

Despite the measures taken to protect the consumer as in the European and international market we conclude that we 
have one of his discrimination. Consumer protection is presented one of the main areas that are directly related to the protection of human rights. Regulation of this area is based on three main pillars as they are consumer health, safety and protection of consumer rights and economic interests of consumers. Law no. 9902 dated 17.04.2008, "On consumer protection", as amended, constitutes the basic legislation on the right, where the Ombudsman is entitled to a special role in its Article 56 on the protection of consumers' interests not only for complaints individual, but also cases of a wider community across the country. Ombudsman institution in order to exercise the constitutional and legal powers to protect the rights and legitimate interests of consumers found problematic food security and expired goods which circulate in the market and not destroyed by commercial entities. For this occasion we asked the relevant authorities monitoring and constant checks to commercial entities, the disposal of products in cases where they find that they are expired and the imposition of punitive measures against commercial entities.

\subsection{The role of Ombudsman in Albania}

Also, we found problematic the case published in the media on the content of a high amount of aflatoxin in milk that has been circulating not only in the Albanian market, and to whom we have recommended the setting of standards on the quality of food products, in respect of the Constitution the Republic of Albania, when the life of a person is protected by law, in order to avoid cases when violated or endanger the lives of consumers and the application of Common Strategy for consumer Protection and Market Supervision (2007-2013), approved by DCM. 797 dated 14.11.2007.

Another case launched ex officio, has to do with the implementation of measures by the Municipality of Kukes for bill payments drinking water from economic aid, where all beneficiaries of social assistance is made stops in value $18 \%$ for payment of bills drinking water and the same scheme Municipality has applied for the collection of local taxes in each year. Ombudsman as a constitutional institution in fulfilling its duties and constitutional functioning, has found that the actions of the Municipality for the collection of taxes of drinking water bills, making stops economic aid, are actions that contradict the open with the law. Undoubtedly, that our institution is not pro making public service, in this case drinking water supply and its failure to pay by the customer, but the current legislation foresees other sanctions for persons resulting debt related to the payment of public services. Referring to Article 52 of the Constitution of the Republic of Albania to the point "2" to his forecast that: "Everyone, who remains without work for reasons independent of his will and when no other means of support, has the right to social assistance under the conditions provided by law ". In the context of this article, the nature of economic assistance to individuals who have lack of employment is an expression of social protection established through the fulfillment of social objectives and therefore their implementation is closely linked to the state's obligation to make guaranteeing and providing adequate funds for vital needs.

Another focus of activity of the Ombudsman for the protection of consumer rights and particularly those vulnerable groups as they are also persons with disabilities, have been recommendations to the Public Administration bodies just as the Ministry of Social Welfare and Youth / Ministry of Finance for the release of funds associated with the subsidy payments of electricity bills. Specifically, in 2012, Law 26/2012 dated 05.04.2012 "On Amendments to the Law no. 8098 dated 28.03.1996, "On the status of the Blind" and the Law no. 27/2012, "On amendments to Law no. 8626 dated 22.06.2000, "On the status of the paraplegic and quadriplegic", article 12 of them underwent changes as follows: "paraplegic and tetraplegic, blind and who have acquired the status, compensation benefit energy bill electricity and landline telephone bill. Measures, criteria and procedures for the benefit of the financial compensation shall be determined by the Council of Ministers ". With the changes that suffered the above law, the Company "CEZ Distribution" JSC proceeded to subsidize electricity bills by the end of April 2012. Thereafter to all customers who enjoy the status of the paraplegic and quadriplegic, blind and proceeded to full payment of electricity bills as defined in Decree No. 404 dated 20.06.2012, "For the purpose of determining the criteria and procedures of obtaining financial compensation for persons with the status of blind and paraplegic and quadriplegic, the electricity bill and fixed phone bill". In the above Decree states that:

1. Individuals beneficiary status under the Law No. 8626, dated 22.06.2000, "On the status of invalids, paraplegics and quadriplegics", as amended, who need a guardian, was given compensation for bill electricity at the rate of 2000 leks per month.

2. Individuals beneficiary status under the Law no. 8098, dated 28.03.1996, "On the status of the blind", as amended, need for caregivers, were given compensation for the electricity bill, to the extent 2000 leks per month.

3. Individuals beneficiary status under the Law no. 8626 , dated 22.06 .2000 , "On the status of invalids, paraplegics and quadriplegics", as amended, and individuals beneficiary status under the Law no. 8098 dated 
28.03.1996, "On the status of the blind", as amended, who did not need a guardian, was given compensation for electricity bill Lek 1,400 per month.

4. The amount of compensation is calculated and obtained at the local government unit where the individual is blind, paraplegic and quadriplegic, it has a residence ......

In the analysis of the above legal provisions, the Ombudsman Institution, has sought not only to mobilize the authorities, but they sensitize them to the importance that has this problem as it is subsidies and payments to people with disabilities limited to public services provided electricity as it is. For the above, we requested that concrete actions dealing with the disbursement of funds for realization of this process (subsidizing electricity bills) within a shortest possible time in order to protect and benefit of all rights persons with disabilities for a life as normal as possible, the real barriers and socio-economic integration. ${ }^{1}$

\section{Conclusions}

Each of us are consumers of goods and services. Quality service delivery is not the same for all persons. The reasons for not equal enjoyment of treatment are different consumers such as race, sex, age ect... In this paper we concluded that consumers do not enjoy the same treatment in the market so, as in the international, European and national level. Measures taken out show for a reduction or elimination of discrimination discrimination consumer, the statistics speak to the contrary. Despite their customer is discriminated against, directly or indirectly.

Ombudsman has played and is playing an important role in consumer protection, for the first time he was introduced by law in 2008. The forecast of this defense mechanism was to be the guarantor of consumer protection. In practice, many cases have been found where consumer rights are violated, to give customers solutions to their problems are drejtauar Ombudsman. In many cases the Ombudsman has concluded that consumer rights are violated and thus institutions and competent authorities have taken measures to protect consumers.

\section{References}

Ahmeti, A. (2006). The right of the consumer and the approximation of legislation with Community law. The School of Magistrates. Anastasi, A., Bozo, A., Mandro, A., \& Shkurti, E. (2014). Barazia gjinore dhe mosdiskriminimi. Tirane: Pegi.

Annual analysis of NFA.( 2015). 1, 10-13.

Annual Report On the activity of the Ombudsman 1 January - 31 December 2013

Halilaj, B. (2015). Consumer Food Safety in Albania. Academic Journal of Interdisciplinary Studies. 4, 171.

Law No. 8192 dated 06.02.1997 " On consumer protection ".

Law No. 9135 dated 11.09.2003 " On consumer protection ".

Law No. 9902 dated 17.04.2008 "On protection of consumers".

Law Nr. 9199, dated 26/02/2004 "On the production, processing, certification and marketing of products" Bio "

Malltezi A.(2001). E drejta shqiptare e shoqerive tregtare, Tirane: mediaprint.

Omari, L. (2004). Shteti i se drejtes, Tirane: Elena Gjika.

Stabilization and Association Agreement. (2009). 